\title{
Socio-economic factors and management regimes as drivers of tree cover change in Nepal
}

\author{
Sujata Shrestha ${ }^{1}$, Uttam B Shrestha ${ }^{\text {Corresp., }}{ }^{2}$, Kamal Bawa ${ }^{1,3}$ \\ 1 Department of Biology, University of Massachusetts at Boston, Boston, MA, United States \\ 2 Institute for Agriculture and the Environment, University of Southern Queensland, Toowoomba, QLD, Australia \\ 3 Ashoka Trust for Research in Ecology and the Environment (ATREE), Bangalore, India \\ Corresponding Author: Uttam B Shrestha \\ Email address: Uttam.Shrestha@usq.edu.au
}

Despite the local and global importance of forests, deforestation driven by various socioeconomic and biophysical factors continues in many countries. In Nepal, in response to massive deforestation, the community forestry program has been implemented to reduce deforestation and support livelihoods. After four decades of its inception, the effectiveness of this program on forest cover change remains mostly unknown. This study analyses the spatial and temporal patterns of tree cover change along with a few socio-economic drivers of tree cover change to examine the effectiveness of the community forestry program for conserving forests or in reducing deforestation. We also investigate the socioeconomic factors and policy responses as manifested through the community forestry program responsible for the tree cover change at the district level. The total tree cover area in the year 2000 in Nepal was $\sim 4,746,000$ hectares, and our analysis reveals that between 2001 and 2016, Nepal has lost 46,000 ha and gained 12,300 ha of areas covered by trees with a substantial spatial and temporal variations. After accounting socioeconomic drivers of forest cover change, our analysis showed that districts with the larger number of community forests had a minimum loss in tree cover, while districts with the higher proportion of vegetation covered by community forests had a maximum gain in tree cover. This indicates a positive contribution of the community forestry program to reducing deforestation and increasing tree cover. 
1 Socio-economic factors and management regimes as drivers of tree cover change in Nepal

2 Sujata Shrestha1, Uttam Babu Shrestha ${ }^{2 *}$, Kamal Bawa ${ }^{1,3}$

3

$4{ }^{1}$ Department of Biology, University of Massachusetts Boston, Boston MA, 02125, USA

$5 \quad{ }^{2}$ Institute for Agriculture and the Environment, University of Southern Queensland, Toowoomba

6 QLD, 4350, Australia

$7 \quad{ }^{3}$ Ashoka Trust for Research in Ecology and the Environment (ATREE), Bangalore, India

$8 *$ corresponding author $=$ ubshrestha@yahoo.com

9

10 


\section{Abstract}

12 Despite the local and global importance of forests, deforestation driven by various socio-economic and biophysical factors continues in many countries. In Nepal, in response to massive

14 deforestation, the community forestry program has been implemented to reduce deforestation and support livelihoods. After four decades of its inception, the effectiveness of this program on forest cover change remains mostly unknown. This study analyses the spatial and temporal patterns of tree cover change along with a few socio-economic drivers of tree cover change to examine the effectiveness of the community forestry program for conserving forests or in reducing deforestation. We also investigate the socio-economic factors and policy responses as manifested through the community forestry program responsible for the tree cover change at the district level. The total tree cover area in the year 2000 in Nepal was $\sim 4,746,000$ hectares, and our analysis reveals that between 2001 and 2016, Nepal has lost $\sim 46,000$ ha and gained $\sim 12,300$ ha of areas covered by trees with a substantial spatial and temporal variations. After accounting socioeconomic drivers of forest cover change, our analysis showed that districts with the larger number of community forests had a minimum loss in tree cover, while districts with the higher proportion of vegetation covered by community forests had a maximum gain in tree cover. This indicates a positive contribution of the community forestry program to reducing deforestation and increasing tree cover.

\section{Introduction}

31 Forests play multiple roles in climate regulation, protection from extreme events, water filtration, carbon sequestration, and biodiversity habitat apart from providing provisioning ecosystem services such as food, timber, and medicines (Lambrechts et al., 2009; Anderegg et al., 2013). 
34 Forests regulate regional and global climate through evapotranspiration, which in turn affects the

35 precipitation regime and the water cycle (Chagnon and Bras, 2005). About 45\% of carbon found

36 in terrestrial ecosystems is stored in forests, and forests sequester more than $25 \%$ of annual

37 anthropogenic carbon emissions from the atmosphere (Pan et al., 2011). Forests, with the majority

38 of the world's terrestrial species of plants, animals, and microorganisms, are also one of the richest

39 biological areas on Earth (Lindenmayer et al., 2000). Furthermore, about 1.3 billion people,

40 primarily in developing countries, rely on forests for their subsistence livelihoods and a significant

41 part of cash income (Wasiq and Ahmad, 2004).

42

Despite the important and critical role forests' play in maintaining essential functions of our planet and in human welfare, the process of converting forested land to other land uses such as cropland, pasture, mining, and urban areas is persistent (Keenan et al., 2015). Although the rate of deforestation has slowed down in recent years, it is still alarmingly high (FAO, 2010). About 13 million hectares (ha) of forests were lost annually from 2010 to 2015 at the global scale, and the extent of forest loss is higher in tropical countries (Hansen et al., 2013; FAO, 2015), where biological diversity as well as reliance on forests for subsistence level livelihoods, are the highest. Deforestation has caused degradation of quality and amount of ecosystem services around the world reducing biodiversity, undermining the flood retention capacity and soil stability as well as producing negative impacts on local livelihoods and regional economies (Wagner et al., 2015).

53 The global deforestation is causing a significant amount of carbon emission (8-10\% of total) 54 contributing to global climate change and environmental degradation affecting human wellbeing 55 (Le Quéré, 2016; Lambrechts et al., 2009). Therefore, efforts for accurate monitoring of forests at 
56 57 2014).

58

59

60

61

62

different scales have received particular attention in recent years (FAO, 2015; Shimada et al.,

\section{Forest cover change and its drivers}

Deforestation is influenced by a wide range of factors such as agricultural expansion, insecure land tenure, international markets, colonization, infrastructure and road building, urbanization, mining, grazing, uncontrolled fire, political unrest, fuelwood extraction, and timber logging (Angelsen and Kaimowitz, 1999; Geist and Lambin, 2002; Rudel et al., 2009; Ferretti-Gallon and Busch, 2014). Various demographic, socioeconomic, biophysical, political, cultural, and technological drivers, acting individually or synergistically, stimulate the anthropogenic activities of the agents (i.e., small farmers, ranchers, plantations, loggers) causing deforestation or forest degradation (Angelsen and Kaimowitz, 1999; Kissinger et al., 2012). For example, increase in human population requires more land for food, space, and other commodities resulting in the conversion of forest areas into agriculture or other land uses (Kanninen et al., 2007). A synthesis of more than 140 economic models analyzing the causes of tropical deforestation showed that more roads, higher agricultural prices, lower wages and a shortage of off-farm employment lead to more deforestation, while the effect of technical change, agricultural input prices, household income levels and tenure security on deforestation is unknown, and the role of macroeconomic factors such as population growth, poverty reduction, national income, economic growth, and foreign debt on deforestation is ambiguous (Angelsen and Kaimowitz, 1999). However, the drivers of deforestation vary across geographical locations and historical contexts; over the last 50 years, the 
agents of deforestation have changed (Laurance and Balmford, 2013). Historically, forests were cleared for crops or livestock, and small farmers were considered as a major driver of deforestation. Conversely, after economic globalization since 1990, forests have been cleared for massive agricultural expansion, road building, wood extraction, and infrastructure development (Rudel et al., 2009; Laurance and Balmford, 2013). A large-scale agriculture expansion for cattle ranching, soybean and palm oil production, and timber logging is causing deforestation in many countries such as Brazil and Indonesia (Brown et al., 2005; Morton et al., 2006; Arima et al., 2011).

Various approaches were adopted globally such as the establishment of protected areas, forest restoration, protection and afforestation activities, and provision of economic incentives to reduce and prevent deforestation or forest degradation (Brooks et al., 2012; Le Saout et al., 2013). Around $15.4 \%$ of the world's land area (Deguignet et al., 2014) and about $24 \%$ of the total area of Nepal are covered by protected areas (GoN, 2014b), which have contributed to reducing deforestation and conserving forests. As an alternative to strict protection, as practiced in protected areas, community-based conservation initiatives such as community forestry program adopted in Nepal and other developing countries also plays a successful role in forest protection (Brooks et al., 2012; Porter-Bolland et al., 2012). More recently, reforestation has been a global phenomenon, and many developing countries have undergone through a forest transition $-\mathrm{a}$ shift from net loss to a net increase of forest cover (Meyfroidt and Lambin, 2011). During 1990-2015, a net loss of the forest area has been slowing down and afforestation has increased at a global scale primarily in 13 tropical countries, forest transition has undergone since 1990 (Sloan and Sayer, 2015). Forest transitions result from various trends such as natural regeneration of forests, forest plantation, and adoption of agroforestry (Meyfroidt and Lambin, 2011). Migration of farmers from rural areas to 
102 urban centres and economic shift from agriculture to industry and services stimulate forest 103 recovery and gain (Aide and Grau, 2004). In the context of South Asia including Nepal, 104 reforestation and regrowth of forest are attributed to human drivers particularly to the devolution 105 of forest management to local communities in the form of community forestry (Nagendra, 2009).

107 Globally, community forest management (CFM) has been considered a promising approach to 108 sustainable forest management over the past few decades (Arnold, 2001). Although CFM has various definitions and interpretations, CFM is a government-approved form of forest management in which the rights, responsibilities, and authority for forest management rest, at least in part, with local communities (Newton et al., 2015). The primary aim of CFM is maintaining ecological sustainability (reduce deforestation, preserve biodiversity) while improving livelihoods of the local community (Bowler et al., 2012). Despite some examples of CFM failures (Tole, 2010; Bowler et al., 2012), in many countries, it has produced successful outcomes such as improvement of forest cover, increase in plantation zones, equity of benefit sharing, or reduction of community poverty (Pagdee et al., 2006). In some tropical countries, the community managed forest plays more important role in maintaining forest cover than protected areas; community forestry has lower deforestation rates than protected areas do (Porter-Bolland et al., 2012). Despite these mixed

119 outcomes, CFM is the widespread approach to forest management in developing countries 120 including Nepal. In the context of climate change, CFM is now viewed as an option to reduce 121 greenhouse gas emission through REDD+ (Reducing Emissions from Deforestation and Forest 122 Degradation), a global climate change mitigation mechanism, which has been under negotiation 123 by the United Nations Framework Convention on Climate Change (UNFCCC) (Agrawal and 124 Angelson, 2009). 
126 Nepal has a promising history of forest management and shows an excellent example of

127 community-based forest conservation globally although the country has only 5.96 million hectares

128 forests $(40.36 \%$ of the country's land area). Concerned with massive deforestation and forest

129 degradation in the early 1970s, Nepal initiated one of the most extensive community forestry (CF)

130 programs in the world by handing government-controlled forests over to community forestry users

131 groups (CFUGs) formed by local communities through an enactment of the Panchayat Forest Rules

132 (Acharya, 2002). Since then about 1.8 million ha of the forest areas have been handed over to and

133 managed by, 19,361 CFUGs (approximately 1.45 million households or 35\% of Nepal's

134 population) under community-based forest management program (DoF, 2015). The community

135 forests provide various ecosystem goods and services to the local communities and help to global

136 communities by sequestering a significant amount of carbon. Nepal has recently jointed to the

137 United Nations collaborative initiative on REDD+ program — one of the leading global efforts to

138 reduce deforestation to mitigate climate change, prepared a Readiness Preparation Proposal (R-

139 PP), and formed REDD+ institutional framework (MoFSC, 2012; UN-REDD, 2014). Finally,

140 under the most recent United Nations Framework Convention on Climate Change (UNFCCC)

141 agreement in Paris to reduce emissions, Nepal's Intended Nationally Determined Contributions

142 (INDCs) to emissions assign a vital role to forests. Nepal aims to enhance forest carbon stock by

$1435 \%$ by 2025 as compared to 2015 levels and decrease mean annual deforestation rates by $0.05 \%$

144 from $0.44 \%(D F R S, 2015)$.

145

146 Nepal does not have a long-recorded history of deforestation or forest cover change. The initiation

147 of large-scale monitoring of forest cover change occurred only after 1960 although deforestation 
148 has been a major issue in Nepal. From 1964 to 1994, about 2.1 million ha of forests were converted 149 to shrubland or other land uses (Acharya et al., 2015). FAO data showed that the annual loss of 150 forest in the period between 2000 and 2005 was $1.39 \%$, which remained stable during 2005-2010 151 (FAO, 2010). However, forest cover change at the national level has not been assessed in Nepal 152 after the second National Forest Inventory in 1999; therefore, there is no critical information 153 available about forest cover change at the national level in Nepal in recent years (DFRS, 2015). 154 Most of the recent studies on forest cover change were conducted in small areas (Uddin et al., 155 2015a; Uddin et al., 2015b; Niraula et al., 2013; Poudel et al., 2015). Some recent studies have 156 outlined both drivers and underlying causes of deforestation and forest degradation in Nepal. A 157 total of nine major drivers of deforestation and forest degradation: i) forest fire, ii) overgrazing, 158 iii) unsustainable utilization of forest products, (iv) weak forest management practices, (v) 159 infrastructure development, (vi) urbanization and resettlement, (vii) encroachment, (vii) invasive 160 species, (ix) mining were identified (REDD Implementation Center, 2013). Likewise, population 161 distribution, migration, poverty, high dependency in forest products, insecure forest tenure are 162 major underlying causes of deforestation and forest degradation in Nepal (Acharya et al., 2015). 163 We use available data on the drivers and underlying causes of deforestation and analyse: a) the spatial and temporal patterns of the tree cover change in Nepal from 2001-2014, b) the socioeconomic drivers of forest cover change, and c) the effectiveness of community forestry programs on the tree cover dynamics. Our efforts mark the first attempt to analyse the tree cover change for

167 the entire country (albeit at the district level), relate this loss and gain to socio-economic drivers, 168 and identify policy-relevant interventions (community forestry) needed to stem deforestation and 169 forest conservation. 


\section{Materials and Methods}

172 Study area

173 Nepal provides an excellent case study to understand the effectiveness of community-based

174 institutions on forest conservation as a significant portion of the forests of this country is managed

175 by local communities. The entire country, Nepal (figure 1) with a geographical area of 147,181

$176 \mathrm{~km}^{2}$, was divided into five physiographic zones-High Himal, High Mountain, Hill, Siwalik, and

177 Terai-based on climate, soil, elevation, topography, vegetation and forest types (LRMP, 1986).

178 Forest and agriculture sectors have the highest contributions to the national gross domestic product

179 (GDP), contributing 26.1\% share of the total GDP of Nepal (CBS, 2015b). About 69\% of the 180 employed population in Nepal is engaged in agriculture, forestry, and fishing (CBS, 2015a). The

181 country is politically divided into 75 districts; the district is the lowest spatial unit used here for 182 data analysis, as most of the demographic, socio-economic, and environmental data are available 183 only at the district level in Nepal. We believe that district-level analyses do not compromise data 184 availability and spatial accuracy.

\section{Tree cover data}

187

188

189

190

191

192

193

We used a subset of global tree cover data provided by global forest watch (Hansen et al., 2013, updated every year). The global forest watch offers the highest resolution datasets (30m ground resolution) of tree cover using Google Earth Engine and Landsat's satellite imagery for the entire globe. The data show both the extent and change of tree cover globally (Hansen et al., 2013). We called it tree cover, however; it is synonymously called forest cover. Unfortunately, there is no shared definition of forests globally. Generally, forests are defined for specific purposes, based on views, concepts, and priorities (Chazdon et al., 2016). Three common criteria: canopy cover, 
194 intact-area, and the height of the trees are commonly used for defining forests, but these criteria 195 are not uniformly used by different agencies and countries. For example, Food and Agriculture 196 Organization of the United Nations (FAO) uses $5 \mathrm{~m}$ for the height of trees, $10 \%$ crown cover and 1970.5 ha for minimum size of forest (Lambrechts et al., 2009) whereas United Nations Framework 198 Convention on Climate Change (UNFCC) calls forests for area of 0.05-1 ha with 10-30 \% canopy 199 and $>2-5 \mathrm{~m}$ tall trees (Sasaki and Putz, 2009). These differences in definitions and methodologies 200 used to map and monitor forests often lead to differing results (Lambrechts et al., 2009). 201 Furthermore, the definition and assessment issues have handicapped the efforts to understand the 202 tree cover dynamics (Rudel et al., 2016). The definition of tree cover adopted for this study was 203 'all the vegetation area greater than 5 meters in height with the canopy cover of at least $30 \%$ ' as 204 used by Hansen et al. (2013) since we used Hansen's data from the Global Forest Watch. We 205 disaggregated tree cover change (loss and gain) data for the 75 districts and five physiographic 206 zones of Nepal.

207

Drivers of tree cover change and policy responses

209 According to Angelsen and Kaimowitz (1999), the framework of deforestation should consider five types of variables (the magnitude and location of deforestation as a dependent variable, the agents of deforestation, the choice variables, agents' decision parameters, the macroeconomic variables, and policy instruments) in the models of deforestation. We selected a list of potential factors of deforestation and forest degradation in the context of Nepal after carefully reviewing the literature on global and local drivers of-and causes to-forest cover change, while also considering the availability of data. We did not consider some factors associated with deforestation and forest degradation identified by previous studies (Angelsen and Kaimowitz, 1999) as relevant 
217 to Nepal. For example, some of the immediate causes of deforestation listed by Angelsen and

218 Kaimowitz (1999) such as agriculture prices, prices of agricultural inputs and credit and underlying

219 causes of deforestation such as timber prices, external debt, trade and structural adjustment may

220 be associated with deforestation in Nepal but the data is not available.

221

222 Data on various factors associated with deforestation and forest degradation such as demographic 223 (population density, migration), economic (poor people density, livestock density), social (human

224 development index, percentage of households using fuelwood for cooking), and environmental

225 (fire, road length, elevation, slope) along with the policy response variables (number of community

226 forest user groups and the share of the major vegetation area covered by community forest) were

227 gathered from various sources (Table 1). In the following paragraphs, we provide our justification

228 for selecting these factors.

229 The population is widely seen as an underlying driver of deforestation (Angelsen and Kaimowitz, 230 1999; Kissinger et al., 2012). In the natural resource-dependent country like Nepal, population 231 growth increases demand for natural resources primarily forests and requires more lands for 232 habitation. As the population grows, more people are living in the cities, and urbanization is 233 considered as one of the major drivers of deforestation in Nepal (REDD Implementation Center, 234 2013). A high unemployment rate coupled with population growth has accelerated both domestic 235 and international migrations in Nepal, and the country has emerged as a remittance-dependent 236 economy shaped by the earnings of labour migrants for foreign employment. Remittance 237 contributes around 29\% to the Gross Domestic Product (GDP) of Nepal, making the nation top 238 third among the countries in terms of remittance contributions to GDP (World Bank, 2016). 239 Migration particularly labour migration has resulted in land abandonment and the conversion of 
240 agricultural land into other land use such as forests, shrubs or fallow in some areas (Paudel et al.,

241 2014). Therefore, population density and migration are considered as dependent variables in our

242 model. We used the most recent national population census as a demographic variable (CBS,

243 2012). We also included the data on out-migration (the number of people migrated abroad for

244 employment as there is no data on internal migration available) (GoN, 2014a). To normalize the

245 effect of the district size, we calculated the number of migrant per unit area in a district by dividing

246 the total number with the area of a district outside the protected areas and used in the model.

248 Human development index, which measures income, health, and education, is linked with deforestation and hence incorporated in our model; countries with low HDI has a high rate of 250 deforestation and vice versa (Jha and Bawa, 2006). Although income and poverty are correlated, poverty is a multidimensional social phenomenon (Anand and Sen, 1997). There is a high rate of

252

poverty in naturally forest-dense areas, and poverty is considered as an important underlying cause of forest conversion by smallholders (Chakravarty et al., 2012). However, the linkage between poverty and forest degradation is ambiguous (Angelsen and Kaimowitz, 1999) and the natural resource degradation may depend on a complex range of choices and tradeoffs available to the poor (Barbier, 2010). Nepal still has a large number of people living in poverty and has a low score in HDI. Therefore, we accounted for HDI and poverty in our model. District wise figures of HDI and number of poor people obtained from the latest human development report (NPC/UNDP, 2014). To normalize the effect of the district size, we calculated the number of poor people per unit area (poor people density) in a district and used in the model. 
262 Overgrazing is considered as one of the major drivers of forest loss and degradation in Nepal

263 (Acharya et al., 2015; REDD Implementation Center, 2013). Grazing in the forested areas and

264 stripping trees to provide fodder for animals are common in many parts of Nepal. Therefore, we

265 considered this as a variable to our model. The most recent data of livestock were acquired from

266 the statistical information on Nepalese Agriculture (GoN, 2012a). Since the populations of pig,

267 poultry, and fowl do not have a direct impact through grazing on forests, we excluded them from

268 the populations of cattle, buffalo, sheep, and goat and used as the livestock number. We calculated

269 the livestock ratio by dividing the livestock number with the extent of the major vegetation cover

270 of each district assuming the pressure of these livestock exerts mainly on vegetation. The

271 vegetation area (cumulative area of forests, shrubs, grasslands and sparse vegetation) for a district

272 was calculated by using a global land cover share map, version 1.0 (Latham et al., 2014).

273

274 Although fire can be a helpful tool for forest management, it can be a significant cause of 275 deforestation if abused (Chakravarty et al., 2012). Forest fire induced by humans is one of the key 276 drivers of forest degradation in Nepal (Matin et al., 2017). We used the burned area products 277 (MCD45) of the MODIS satellites. We calculated a yearly total number of fire pixels from the monthly images of Geotiff version. Annual fire incidence (number of pixels) was then clipped by

279 the extent of vegetation to exclude fire occurred outside the potential forest area. Total pixels of 280 the yearly fire incidences were counted in each district. We later combined all the annual values 281 from 2001-2016 and the aggregated value was used in the model.

283 Fuelwood gathering is considered as one of the causes of deforestation and forest degradation in 284 tropical areas (Chakravarty et al., 2012). In rural areas of Nepal, wood derived from natural forests 
285 is one of the most critical sources of fuelwood (Christensen et al., 2009). Fuelwood contributes

286 about $70 \%$ of the total energy supply for the rural population of Nepal (Kandel et al., 2016).

287 Therefore, we included fuelwood gathering as a variable in our model. We collected district wise

288 data of the total number of households used fuelwood for cooking from the national population

289 and housing census (CBS, 2012). We calculated the percentage of households in a district using

290 fuelwood for cooking to use as a predictor in the model.

291

292 Proximity to the roads affects forest condition; forests closer to roads in the distance are more

293 likely to be cleared (Liu et al., 1993; Lambin, 1997). In rural Nepal, there has been a prolific

294 growth of earthen road expansion in recent years. Due to the mountainous topography, steep

295 slopes, and weak soils, these poorly constructed rural roads have increased the probability of

296 landslides especially during the heavy monsoonal rainfall (Leibundgut et al., 2016). Therefore,

297 road buildings may have an impact on the condition of forests and we considered the length of the

298 road as a variable in our model. The data on roads were collected from the Department of Roads,

299 Nepal (GoN, 2012b). We also used digital elevation data (DEM) from Shuttle Radar Topographic

300 Mission (SRTM) (http://srtm.csi.cgiar.org/) and calculated slope from DEM in ArcGIS to use in

301 our regression model.

302 We used the total number of CFUGs and the proportion of the vegetation area covered by

303 community forests in a district as a proxy to measure the effectiveness of community forestry

304 programs. The data on the number and area of CFUGs were obtained from the Management

305 Information System maintained by the Department of Forests, Nepal (DoF, 2015). To normalize

306 the non-forested area effect, the total area of community forests in a district was divided by the

307 major vegetation area of that district because the government handed over only the area covered 
308 by potential vegetation (forests, grasslands, shrubs, and sparse vegetation areas) to the local 309 community as the community forests.

Data analysis

312 We analysed the net change, loss, and gain of tree cover for each district over a 16-year period

313 from 2001 to 2016 . Because protected areas cover a significant area of Nepal (about $24 \%$ of the

314 total land area) and have a separate management system, the geographical areas covered by

315 protected areas were excluded in further analysis to determine the impacts of the drivers of 316 deforestation and effectiveness of the community forestry program on the gain and loss of tree

317 cover. We build three models; in the first model, the proportion of tree cover loss was used as a

318 dependent variable, in the second, proportion of tree cover gain and the proportion of net change

319 in tree cover in the third model. The demographic, economic, social, and environmental variables

320 were used as independent variables in both models. After testing our data with the assumptions

321 required for multiple linear regressions (heteroscedasticity, normality, outliers, multicollinearity),

322 we conducted the ordinary least square (OLS) regression analysis to predict the impact of 323 independent variables on the dependent variables. We examined multicollinearity among predictor 324 variables (Supplementary figure 1$)$ and eliminated highly correlated $(r>0.75)$ two variables (poor 325 people density and slope) resulting in 10 independent variables for the initial models. We used 326 stepwise model selection method on R software package to select the final model (R Core Team, 327 2017). The initial models were evaluated by using Akaike Information Criteria (AIC), the 328 commonly applied criterion to compare models for the goodness of fit and the model with the 329 smallest AIC was chosen as the best-fit model (Burnham et al., 2004). 
331 As the socio-economic data were available at the district level, we choose 75 districts as study

332 units. We conducted area-based correction for the dependent variables (tree cover loss and gain)

333 to normalize the effect of the district size. Rather than using total area of tree cover loss and gain,

334 we used proportions of forest that were lost, gained and changed in the district as the dependent 335 variable in the regression models.

336

337 We also quantified the spatial pattern of tree cover loss to observe the spatial association between roads and the loss and gain of tree cover, using the GIS-based buffering approach, from one to

339 five-kilometre distance from the current road networks. We counted the total number of pixels of tree cover loss and gain within a range from one to five kilometres from the roads and calculated the total areas. Since we have temporal data of forest fire incidence and forest fire is considered a major driver of deforestation and forest degradation in Nepal, we also compared annual trends of tree cover loss with the trends of the forest fire.

We visually compared the tree cover loss data with the high-resolution images of the Google Earth

Pro. We first identified 132 larger patches of tree cover loss and randomly selected 50 patches by overlaying $1 \mathrm{~km}^{2}$ grids on the layer of tree cover loss. We visually compared the images captured around 2001 with the images captured around 2016 in those loss patches using the Google Earth

350 (Supplementary figure 2).

\section{Results}


353 The total tree cover area in the year 2000 in Nepal was 4,746,000 hectares. Nepal has lost 46,000

354 ha and has gained 12,200 ha areas of tree cover over the last 16 years from 2001-2016. However,

355 a substantial spatial variation was observed among physiographic zones, and districts; maximum

356 loss of tree cover in Siwalik $(28 \%, 13,000 \mathrm{ha})$ followed by Hill $(26 \%, 12,100 \mathrm{ha})$ and Terai $(22 \%$,

357 9,900 ha), Middle mountain (21\%, 98,00 ha) and High mountain (2\%, 1,100 ha). Regarding tree

358 cover gain, the Hill region gained the highest area of 6,200 ha (51\%) followed by Siwalik 3,000

359 ha (25\%), Terai 2,100 ha (17\%), Middle mountain 830 ha (7\%), and High mountain 70 ha (1\%).

361 A major loss in tree cover was observed in Kailali (6\%, 2,270 ha), Dang (5\%, 2,090 ha), Sarlahi

$362(4 \%, 1,730$ ha), Rautahat (3\%, 1,260 ha) and Nawalparasi (3\%, 1,180 ha) districts whereas Kaski

$363(0.09 \%, 34 \mathrm{ha})$ and Bhaktapur $(0.1 \%, 42 \mathrm{ha})$ lost comparatively a smaller area of tree (Figure 2$).$

364 In terms of gain in tree cover, Dang with 880 ha (7\%) forest gain was at the top position followed

365 by Nawalparasi (7\%, 830 ha), Tanahun (6\%, 650 ha), Palpa (6\%, 620 ha) and Kailali (5\%, 600 ha)

366 districts while Manang (0.01\%, 1 ha), Kaski $(0.01 \%, 1$ ha) and Darchula $(0.01 \%, 1$ ha) gained a

367 lesser forest area. The maximum loss and gain of tree cover were observed within the five-

368 kilometre distance from the roads; the area of forest cover loss and gain decreased as the distance

369 from the roads increased (Figure 3a).

Temporal pattern of forest cover change

372 Over 2001-2016, the maximum loss in tree cover (6,180 ha) occurred in the year 2009 and the 373 minimum (1,040 ha) in the year 2015 (Figure 3b). Likewise, in different physiographic regions,

374 the maximum loss of tree cover in Terai occurred in 2009, Siwalik in 2011, Hill in 2012, Middle 375 mountain and High mountain in 2009. There was no significant correlation between the annual 
376 incidence of the forest fire expressed as the number of pixels with the annual loss of tree cover

$377\left(r^{2}=0.037, p=0.473\right)($ Figure $3 c)$.

378

379 Drivers of change in tree cover

380 We observed the associations between policy response variables (proportion of the major

381 vegetation area covered by community forest and number of CFUGs) and the proportion of tree

382 cover loss and gain by incorporating the effects of demographic factors, economic, social, and

383 environmental factors. The predictor variables identified by the AIC criterion are: number of

384 community forests, livestock density, HDI, migrant density, and elevation for the tree cover loss

385 model. Likewise, a proportion of area covered by community forests, elevation and road lengh

386 were retained for tree cover gain model (Table 2). In the net change in tree cover model, a

387 proportion of area covered by community forests, number of community forests, livestock density,

388 HDI, migrant density, and elevation were retained out of ten predictors. According to our model,

389 the proportion of tree cover loss in a district is significant and negatively correlated with the

390 number of community forests in the district suggesting the districts with a higher number of

391 community forests have a lower amount of tree cover loss (Table 2). Similarly, HDI and elevation

392 had significantly negative correlation with tree cover loss while migrant density had positive

393 association.

394

395 Similarly, the area of tree cover gain was significant and positively associated with the proportion

396 of the major vegetation area covered by community forests demonstrating that districts with a

397 higher the proportion of community forests have a more significant area of tree cover gain. In the

398 net forest change model, the net change in forest cover was significant and negatively associated

399 with the proportion of the major vegetation area covered by community forests and HID and 
400 significant and positively correlated with migrant density (Table 2). HDI, migrant density,

401 proportion of the major vegetation area covered by community forests and the number of

402 community forests were the critical predictors of tree cover change in Nepal.

403

404 Discussion

405 In this study, we disaggregated tree cover (both extent and change) into five physiographic zones 406 and 75 districts of Nepal to compare spatial patterns of tree cover gain and loss. We also observed

407 the temporal profile of the loss in tree cover at two scales, national and regional (physiographic

408 zones). Furthermore, this study identified the demographic, social, economic, and environmental

409 factors of tree cover change and measured the effectiveness of the community forestry program in

410 changing the dynamics of tree cover. Our results are highly relevant to address the socio-economic

411 drivers of tree-cover change as well as to witness the effectiveness of the community forestry

412 program of Nepal.

413

414 Our results on various degree of tree cover loss and gain at district level correspond with the 415 localized studies, which found decrease in forest cover in some areas (Uddin et al., 2015a; Uddin 416 et al., 2015b) as well as increase in forest cover in others (Niraula et al., 2013; Paudel et al., 2014).

417 However, loss of tree cover is more prominent than gain in Nepal at the national scale. This study 418 also confirms the widespread anticipation of the spatial pattern of forest cover change in various 419 physiographic zones; higher rate of deforestation and forest degradation in Siwalik and Terai and 420 the regeneration of forest in the Hill and Middle mountain region (GoN, 2014b). The Terai and 421 Siwalik regions comprise mainly tropical Sal and Mixed Broad-Leaved forest and Hill 422 encompasses Hill Sal forest, Schima-Castanopsis forest, Chir Pine and Chir Pine-Broad Leaved 
423 forests whereas High Mountain region has temperate forests such as Cypress, Rhododendron, 424 Spruce, and Oak Forests (Barnekow Lillesø et al., 2005). From the commercial point of view, Terai 425 and Siwalik regions have forests with maximum market value and are hence highly prone to 426 commercial exploitation (Acharya et al., 2015). In contrast, Terai region has the lowest proportion 427 (7\%) of community forests while Hill and mountain have 75\% and 16\% respectively (GoN, 2013).

428 The total incidence of forest-fire as a whole has a significant and negative impact on the forest, 429 and the relationship can be observed in the temporal pattern in which the annual incidences of 430 forest fire correspond with the annual loss in tree cover. Furthermore, forest-fire is also considered 431 a primary cause of forest disturbance of Nepal (DFRS, 2015) and about 452,000 ha of land areas 432 including forests were burned in Nepal from 2003 to 2012 (FAO, 2015).

434 Our results indicate that the community forestry program played a crucial role in reducing 435 deforestation (tree cover loss) and increasing the forest area (tree cover gain) at the district level. 436 The significant and negative association between the proportion of tree cover loss and the number 437 of community forest shows that districts with a higher number of community forests have lesser 438 areas of loss in tree cover. Similarly, the significant and positive association between the tree cover gain and the percentage of community-forested area in the district indicates a higher proportion of 440 community forests in the districts has a greater gain in tree cover. Community forests combine a 441 mixture of plantations and natural forests, and in most cases, local communities protect the 442 community-owned forests allowing natural regeneration and growth (GoN, 2013). Nevertheless, 443 the tree cover data (Hansen et al., 2013) used here do not distinguish between trees in plantations 444 and natural forests. Therefore, it is not possible to differentiate between regenerating forests due 445 to plantations or from the natural forests. Our study validates the local level studies (Niraula et al., 
446 2013; Gautam et al., 2004; Gautam et al., 2002) and widespread perception that community

447 forestry has a positive impact on the forest cover change by reducing the loss and increasing the

448 gain in forest areas at the district level. Furthermore, an analysis of the CFGUs reports based on

449 the perception of the user groups at national level showed that $79 \%$ of the CFUGs reported an

450 overall increase in tree density in the community forests (GoN, 2013).

451

452 There are other factors that are statistically associated with the tree cover loss such as migrant

453 density; the higher density of migrant workers in a district, the greater the areas of tree cover loss.

454 The positive association between forest loss and migrant density makes sense as the temporary

455 migration for employment may increase demand for natural resources as the households of

456 migrants receive remittance that may prompt construction activities creating more pressure to

457 forests. Significant and negative association between the tree cover loss and HDI values indicates

458 the districts with higher levels of development has lesser tree cover loss. Studies found that HDI

459 as a crucial predictor of forest transition (Redo et al., 2012) and a lower rate of deforestation (Jha

460 and Bawa, 2006). Lack of development and economic opportunities in the districts with low HDI

461 may make people rely heavily on forest resources for subsistence use (Angelsen et al., 2014;

462 Belcher et al., 2015) that might lead to the extraction of more forest resources causing deforestation

463 and forest degradation.

464

465 Although we didn't find any correlation between road length and the change in tree cover, spatial

466 concomitance between road and forest grain and loss might lead to a positive relationship between

467 forest cover loss and road network. Construction of the road might lead to the cutting of trees and

468 facilitate forest encroachment. Due to the steepness in the hilly areas, construction of unplanned 
469 earthen roads triggers landslides causing loss of vegetation (Leibundgut et al., 2016). Furthermore,

470 roads were recently built in many rural villages of Nepal, and most of the community forests are

471 located near villages in Nepal. Although fire incidence was considered as a driver of deforestation

472 in Nepal, we didn't find any association between fire incidence and tree cover change. The

473 temporal trend of total annual incidence of forest fire and forest cover loss was very weak. More

474 detail study is necessary to understand the impacts of fire on forests in Nepal as in this study, the

475 unit of analysis is district and there could be a mismatch between the precise localities of forest

476 fire and the tree cover locally.

477

478 The significantly negative correlation between elevation and forest loss suggests the lowlands have

479 the higher proportion of deforestation. This finding concures with the spatial pattern of the 480 deforestation among physiographic zones; terai and siwalik, which are lowland areas of Nepal

481 have the higher amount of tree cover loss. The lowland areas havor trees with high commercial 482 values such as tropical Sal that is highly prone to logging (GoN, 2014b). Bhattarai et al. (2009) 483 found that the amount of deforestation in Nepal particularly central Nepal decreased as the 484 elevation increased and our result also confirms their finding.

485

\section{Conclusion}

487 This study has compromised the spatial accuracy of the higher resolution of data with the 488 availability of data at some extends. An analysis at a finer spatial scale would have produced a 489 more nuanced view. Unfortunately, there is no spatial information (maps with boundary) available 490 for all the CFUGs in Nepal. Although the analysis at the village development committees (VDCs), 491 the lowest political unit of Nepal could provide more detail overview of tree cover change, the 
492 information on socio-economic drivers is available only at a district level. Despite this shortcoming 493 due to limitations in data availability, our study has highlighted the different factors of 494 deforestation and the effectiveness of the major forest conservation policy in Nepal albeit at a 495 coarse scale. Because of these limitations, the inference of a robust causal relationship between 496 the dependent and independent variables is rather difficult. Globally, the data of tree cover loss 497 provided by Hansen et al. (2013) was correct only 75\% of the time (Weisse and Petersen, 2015) 498 and the data do not differentiate temporary and permanent loss of tree cover between natural forests 499 or tree plantations (Harris et al., 2016). The quality of socio-economic data of developing countries 500 is often criticized (Meyfroidt and Lambin, 2008). Given our limited understanding of the forest 501 cover change in Nepal, the results of this study are useful in formulating policies and programs to 502 address the drivers of deforestation and persistently improve the existing policy on community 503 forestry. We hope that future research with a higher resolution of demographic and socio-economic 504 data (at the scale of community forest) can provide more nuanced results and may identify 505 additional factors associated with forest cover change in Nepal.

Despite some shortcomings due to limitations in data availability and quality, this paper analyses the spatial and temporal patterns of tree cover loss and gain in the light of socio-economic drivers and effectiveness of one of the major forest conservation policies of Nepal. This study addresses 510 a long-term standing policy question regarding the effectiveness of community forestry programs 511 and reveals the likely socio-economic drivers of tree cover change in Nepal. Our results confirm 512 that both the extent of community forestry and the number of CFUGs have positive impacts on the 513 forests. Districts with a higher number of community forests have a minimum loss in tree cover, 514 and the districts with a higher percentage of community forest area have a maximum gain in tree 
515 cover. Although the community forestry program has a positive impact on the forest cover by

516 reducing the forest loss and increasing the gain, the other drivers of forest loss have been leading

517 to the overall decline in forest area in Nepal. Nepal lost almost 46,000 ha forest area while Nepal

518 gained roughly 12,300 ha over 2001-2016. Therefore, in order to conserve forest areas in Nepal,

519 the current policy can be continued and improved if necessary, coupled with addressing the

520 underlying cause of deforestation.

\section{References}

522

523 1. Acharya D, Khanal DR, Bhattarai HP, Gautam B, Karki G, Trines E, van Goor W, Acharya RP. 2015. REDD+ Strategy for Nepal Face the Future. The Netherlands

525

526

2. Acharya KP. 2002. Twenty-four years of community forestry in Nepal. International Forestry Review 4(2):149-156

527

3. Agrawal A, Angelsen A. 2009. Using community forest management to achieve REDD+

528

529

530

531

532

533

534

535

536

537

538

539

540

541

542

543 goals. In Realising REDD+: National Strategy and Policy Options; Angelsen A, Brockhaus M, Kanninen M, Sills EO,Sunderlin WD,Wertz-Kanounnikoff S, Eds.; CIFOR: Bogor, Indonesia, 201-211

4. Aide TM, Grau HR. 2004. Globalization migration and Latin American ecosystems. Science 305(5692):1915-1916Anand S, Sen A. 1997. Concepts or human development and poverty! A multidimensional perspective. United Nations Development Programme, Poverty and human development: Human development papers, 1-20

5. Anderegg WR, Kane JM, Anderegg LD. 2013. Consequences of widespread tree mortality triggered by drought and temperature stress. Nature Climate Change 3(1):30-36

6. Angelsen A, Jagger P, Babigumira R, Belcher B, Hogarth NJ, Bauch S, Börner J, SmithHall C, Wunder S. 2014. Environmental income and rural livelihoods: a globalcomparative analysis. World Development 64:S12-28

7. Angelsen A, Kaimowitz D. 1999. Rethinking the causes of deforestation: lessons from economic models. The World Bank Research Observer 14(1):73-98

8. Arima EY, Richards P, Walker R, Caldas MM. 2011. Statistical confirmation of indirect land use change in the Brazilian Amazon. Environmental Research Letters 6(2):024010 
544

545

546

547

548

549

550

551

552

553

554

555

556

557

558

559

560

561

562

563

564

565

566

567

568

569

570

571

572

9. Arnold JEM. 2001. Forests and people: 25 years of community forestry. Food and Agriculture Organization of the United Nations, Rome, Italy

10. Barbier EB. 2010. Poverty, development, and environment. Environment and Development Economics, 15(6):635-660

11. Barnekow Lillesø JP, Shrestha TB, Dhakal LP, Nayaju RP, Shrestha R. 2005. The map of potential vegetation of Nepal: a forestry/agro-ecological/biodiversity classification system. Center for Skov Landskab og Planlægning/Københavns Universitet

12. Belcher B, Achdiawan R, Dewi S. 2015. Forest-based livelihoods strategies conditioned by market remoteness and forest proximity in Jharkhand India. World Development 66:269-279

13. Bhattarai K, Conway D, Yousef M. 2009. Determinants of deforestation in Nepal's central development region. Journal of Environmental Management 91(2): 471-488.

14. Bowler DE, Buyung-Ali LM, Healey JR, Jones JP, Knight TM, Pullin AS. 2012. Does community forest management provide global environmental benefits and improve local welfare?. Frontiers in Ecology and the Environment, 10(1):29-36

15. Brooks JS, Waylen KA, Mulder MB. 2012. How national context project design and local community characteristics influence success in community-based conservation projects. Proceedings of the National Academy of Sciences 109(52):21265-21270

16. Brown JC, Koeppe M, Coles B, Price KP. 2005. Soybean production and conversion of tropical forest in the Brazilian Amazon: The case of Vilhena Rondonia. AMBIO: A Journal of the Human Environment 34(6):462-469

17. Burnham KP, Anderson DR. 2004. Multimodel inference: understanding AIC and BIC in model selection. Sociological Methods \& Research 33(2):261-304

18. Central Bureau of Statistics (CBS). 2012. Nepal Living Standards Survey. 2010/2011. Government of Nepal. National Planning Commission Secretariat. Central Bureau of Statistics, Kathmandu, Nepal

19. Central Bureau of Statistics (CBS). 2015a. Annual household survey (Major findings). 2014/2015. Government of Nepal. National Planning Commission Secretariat. Central Bureau of Statistics, Kathmandu, Nepal 
573

574

575

576

577

578

579

580

581

582

583

584

585

586

587

588

589

590

591

592

593

594

595

596

597

598

599

600

601

602

603

20. Central Bureau of Statistics (CBS). 2015b. National Account of Nepal. 2014/2015. Government of Nepal. National Planning Commission Secretariat. Central Bureau of Statistics, Kathmandu, Nepal

21. Chagnon FJF, Bras RL. 2005. Contemporary climate change in the Amazon. Geophysical Research Letters 32(13):1-4

22. Chakravarty S, Ghosh SK, Suresh CP, Dey AN, Shukla G. 2012. Deforestation: causes, effects and control strategies. In Global perspectives on sustainable forest management, Okia CA (Ed.), InTech, Croatia.

23. Chazdon RL, Brancalion PH, Laestadius L, Bennett-Curry A, Buckingham K, Kumar C, ... Wilson SJ. 2016. When is a forest a forest? Forest concepts and definitions in the era of forest and landscape restoration. Ambio 45(5):538-550

24. Christensen M, Rayamajhi S, Meilby H. 2009. Balancing fuelwood and biodiversity concerns in rural Nepal. Ecological Modelling 220(4):522-532

25. Deguignet M, Juffe-Bignoli D, Harrison J, MacSharry B, Burgess N, Kingston N. 2014. United Nations List of protected areas. UNEP-WCMC: Cambridge UK

26. Department of Forest (DoF). 2015. Community Forestry National Database: MIS Database Department of Forests (DoF). Community Forestry Division, Kathmandu, Nepal

27. Department of Forest Research and Survey (DFRS). 2015. State of Nepal's Forests Forest Resource Assessment (FRA) Nepal. Department of Forest Research and Survey, Kathmandu, Nepal

28. FAO (Food and Agriculture Organization of the United Nations). 2010. Global Forest Resources Assessment. Food and Agriculture Organization of United Nations, Rome

29. FAO (Food and Agriculture Organization of the United Nations). 2015. Global Forest Resources Assessment. Forestry Paper No. 1. Food and Agriculture Organization of United Nations, Rome

30. Ferretti-Gallon K, Busch J, Ferretti-Gallon K, Busch J. 2014. What drives deforestation and what stops it? A meta-analysis of spatially explicit econometric studies. Center for Global Development. Working Paper 361

31. Gautam AP, Shivakoti GP, Webb EL. 2004. Forest cover change physiography local economy and institutions in a mountain watershed in Nepal. Environmental Management 33(1):48-61 
604

605

606

607

608

609

610

611

612

613

614

615

616

617

618

619

620

621

622

623

624

625

626

627

628

629

630

631

632

633

634

32. Gautam AP, Webb EL, Eiumnoh A. 2002. GIS assessment of land use/land cover changes associated with community forestry implementation in the Middle Hills of Nepal. Mountain Research Development 22(1):63-69

33. Geist HJ, Lambin EF. 2002. Proximate causes and underlying driving forces of tropical deforestation: Tropical forests are disappearing as the result of many pressures both local and regional acting in various combinations in different geographical locations. BioScience 52(2):143-150

34. Government of Nepal (GoN). 2012a. Statistical Information on Nepalese Agriculture. 2012/2013. Government of Nepal. Ministry of Agricultural Development, Agri-Business Promotion and Statistics Division, Statistics Section, Singha Durbar, Kathmandu, Nepal

35. Government of Nepal (GoN). 2012b. Statistics of Strategic Road Network. 2011/2012. Government of Nepal. Ministry of Physical Planning Works and Transport Management, Department of Roads, Nepal

36. Government of Nepal (GoN). 2013. Persistence and Change: Review of 30 Years of Community forestry in Nepal. Ministry of Forests and Soil Conservation, Kathmandu, Nepal

37. Government of Nepal (GoN). 2014a. Labour Migration for Employment. A status report for Nepal: 2013/2014. Government of Nepal. Ministry of Labour and Employment Department of Foreign Employment Nepal

38. Government of Nepal (GoN). 2014b. Nepal Fifth National Report to Convention on Biological Diversity. Government of Nepal. Ministry of Forests and Soil Conservation, Kathmandu, Nepal

39. Hansen M, Potapov PV, Moore R, Hancher M, Turubanova S, Tyukavina A, Thau D, Stehman SV, Goetz SJ, Loveland TR, Kommareddy A. 2013. High-resolution global maps of 21st-century forest cover change. Science 342(6160):850-853

40. Harris N, Peterson R, Davis C, Payne O. 2016. Global Forest Watch and the forest resources assessment, explained in 5 graphics http://blog.globalforestwatch.org/data/global-forest-watch-and-the-forest-resourcesassessment-explained-in-5-graphics-2.html (accessed March 5, 2017)

41. Jha S, Bawa KS. 2006. Population growth, human development, and deforestation in biodiversity hotspots. Conservation Biology 20(3):906-912 
635

636

637

638

639

640

641

642

643

644

645

646

647

648

42. Kandel P, Chapagain PS, Sharma LN, Vetaas OR. 2016. Consumption patterns of fuelwood in rural households of Dolakha district, Nepal: reflections from community forest user groups. Small-Scale Forestry 15(4):481-495

43. Kanninen M, Murdiyarso D, Seymour F, Angelsen A, Wunder S, German L. 2007. Do trees grow on money? The implications of deforestation research for policies to promote REDD. Center for International Forestry Research (CIFOR), Indonesia

44. Keenan RJ, Reams GA, Achard F, de Freitas JV, Grainger A, Lindquist E. 2015. Dynamics of global forest area: results from the FAO. Global Forest Resources Assessment. Forest Ecology \& Management 352:9-20

45. Kissinger GM, Herold M, De Sy V. 2012. Drivers of deforestation and forest degradation: a synthesis report for REDD+ policymakers. Lexeme Consulting Vancouver, Canada

46. Lambin EF. 1997. Modelling and monitoring land-cover change processes in tropical regions. Progress in Physical Geography 21(3):375-393

47. Lambrechts C, Wilkie ML, Rucevska I. 2009. Vital forest graphics. Food and Agriculture Organization of the United Nations, Rome, Italy

48. Land Resources Mapping Project (LRMP). 1986. Land Resources Mapping Project Kathmandu Nepal: Survey Department HMGN and Kenting Earth Science, Nepal

49. Latham J, Cumani R, Rosati I, Bloise M. 2014. Global land cover share (GLC-SHARE) database beta-release version 10-2014. FAO. Rome, Italy

50. Laurance WF, Balmford A. 2013. Land use: a global map for road building. Nature 495(7441):308-309

51. Le Quéré C, Andrew RM, Canadell JG, Sitch S, Korsbakken JI, Peters GP, Manning AC, Boden TA, Tans PP, Houghton RA, Keeling RF. 2016. Global carbon budget 2016. Earth System Science Data 8(2):605

52. Le Saout S, Hoffmann M, Shi Y, Hughes A, Bernard C, Brooks TM, Bertzky B, Butchart SH, Stuart SN, Badman T, Rodrigues AS. 2013. Protected areas and effective biodiversity conservation. Science 342(6160):803-805

53. Leibundgut G, Sudmeier-Rieux K, Devkota S, Jaboyedoff M, Derron M H, Penna I, Nguyen L. 2016. Rural earthen roads impact assessment in Phewa watershed, Western region, Nepal. Geoenvironmental Disasters 3(1):13 
665

666

667

668

669

670

671

672

673

674

675

676

677

678

679

680

681

682

683

684

685

686

687

688

689

690

691

692

693

694

54. Lindenmayer DB, Margules CR, Botkin DB. 2000. Indicators of biodiversity for ecologically sustainable forest management. Conservation Biology 14(4):941-950

55. Liu DS, Iverson LR, Brown S. 1993. Rates and patterns of deforestation in the Philippines: application of geographic information system analysis. Forest Ecology and Management 57(1-4):1-16

56. Matin MA, Chitale VS, Murthy MS, Uddin K, Bajracharya B, Pradhan S. 2017.

Understanding forest fire patterns and risk in Nepal using remote sensing, geographic information system and historical fire data. International Journal of Wildland Fire 26(4):276-86

57. Meyfroidt P, Lambin EF. 2008. The causes of the reforestation in Vietnam. Land Use Policy 25(2): 182-197

58. Meyfroidt P, Lambin EF. 2011. Global forest transition: prospects for an end to deforestation. Annual Review of Environment and Resources 36:343-371

59. Ministry of Forest and Soil Conservation (MoFSC). 2012. Nepal's Readiness Preparation Proposal (R-PP): REDD 2010-2013. Ministry of Forest and Soil Conservation (MoFSC), Kathmandu, Nepal

60. Morton DC, DeFries RS, Shimabukuro YE, Anderson LO, Arai E, del Bon Espirito-Santo F, Freitas R, Morisette J. 2006. Cropland expansion changes deforestation dynamics in the southern Brazilian Amazon. Proceedings of the National Academy of Sciences 103(39):14637-14641

61. Nagendra H. 2009. Reforestation and regrowth in the human dominated landscapes of South Asia in Reforesting Landscapes, ed. J. Southworth, Springer Netherlands Series, 149-174

62. National Planning Commission/United Nations Development Program (NPC/UNDP). 2014. Nepal Human Development Report: Beyond geography unlocking human potential. National Planning Commission, Government of Nepal and United Nations Development Programme, Nepal

63. Newton P, Schaap B, Fournier M, Cornwall M, Rosenbach DW, DeBoer J, Whittemore J, Stock R, Yoders M, Brodnig G, Agrawal A. 2015. Community forest management and REDD+. Forest Policy and Economics 56:27-37 
695

696

697

698

699

700

701

702

703

704

705

706

707

708

709

710

711

712

713

714

715

716

717

718

719

720

721

722

723

724

725

64. Niraula RR, Gilani H, Pokharel BK, Qamer FM. 2013. Measuring impacts of community forestry program through repeat photography and satellite remote sensing in the Dolakha district of Nepal. Journal of Environment and Management 126:20-29

65. Pagdee A, Kim YS, Daugherty PJ. 2006. What makes community forest management successful: a meta-study from community forests throughout the world. Society and Natural Resources 19(1):33-52

66. Pan Y, Birdsey RA, Fang J, Houghton R, Kauppi PE, Kurz WA, Phillips OL, Shvidenko A, Lewis SL, Canadell JG, Ciais P. 2011. A large and persistent carbon sink in the world's forests. Science 333(6045):988-993

67. Paudel KP, Tamang S, Shrestha KK. 2014. Transforming land and livelihood: Analysis of agricultural land abandonment in the Mid Hills of Nepal. Journal of Forest and Livelihood 12(1):11-19

68. Porter-Bolland L, Ellis EA, Guariguata MR, Ruiz-Mallén I, Negrete-Yankelevich S, Reyes-García V. 2012. Community managed forests and forest protected areas: An assessment of their conservation effectiveness across the tropics. Forest Ecology and Management 268:6-17

69. Poudel NR, Fuwa N, Otsuka K. 2015. The impacts of a community forestry program on forest conditions management intensity and revenue generation in the Dang district of Nepal. Environment and Development Economics 20(02):259-281

70. R Core Team. 2017. R: A Language and Environment for Statistical Computing. R Foundation for Statistical Computing, Vienna, Austria. https://www.R-project.org

71. REDD Implementation Center. 2013. Assessment of land use forest policy and governance in Nepal. REDD Implementation Center (RIC). Ministry of Forest and Soil Conservation, Government of Nepal

72. Redo DJ, Grau HR, Aide TM, Clark ML. 2012. Asymmetric forest transition driven by the interaction of socioeconomic development and environmental heterogeneity in Central America. Proceedings of the National Academy of Sciences 109(23):8839-8844

73. Rudel TK, Schneider L, Uriarte M, Turner BL, DeFries R, Lawrence D, Geoghegan J, Hecht S, Ickowitz A, Lambin EF, Birkenholtz T. 2009. Agricultural intensification and changes in cultivated areas 1970-2005. Proceedings of the National Academy of Sciences 106(49):20675-20680 
726

727

728

729

730

731

732

733

734

735

736

737

738

739

740

741

742

743

744

745

746

747

748

749

750

751

752

753

754

755

756

74. Rudel TK, Sloan S, Chazdon R, Grau R. 2016. The drivers of tree cover expansion: Global temperate and tropical zone analyses. Land Use Policy 58:502-513

75. Sasaki N, Putz FE. 2009. Critical need for new definitions of "forest" and "forest degradation" in global climate change agreements. Conservation Letters 2(5):226-232

76. Shimada M, Itoh T, Motooka T, Watanabe M, Shiraishi T, Thapa R, Lucas R. 2014. New global forest/non-forest maps from ALOS PALSAR data (2007-2010). Remote Sensing of Environment 155:13-31

77. Sloan S, Sayer JA. 2015. Forest Resources Assessment of 2015 shows positive global trends but forest loss and degradation persist in poor tropical countries. Forest Ecology and Management 352:134-145

78. Tole L. 2010. Reforms from the ground up: a review of community-based forest management in tropical developing countries. Environmental Management 45(6):13121331

79. Uddin K, Chaudhary S, Chettri N, Kotru R, Murthy M, Chaudhary RP, Ning W, Shrestha SM, Gautam SK. 2015a. The changing land cover and fragmenting forest on the Roof of the World: A case study in Nepal's Kailash Sacred Landscape. Landscape and Urban Planning 141:1-10a

80. Uddin K, Gilani H, Murthy MSR, Kotru R, Qamer FM. 2015b. Forest condition monitoring using very-high-resolution satellite imagery in a remote mountain watershed in Nepal. Mountain Research and Development 35(3):264-277

81. UN-REDD/REDD Cell. 2014. Understanding drivers and causes of deforestation and forest degradation in Nepal: potential policies and measures for REDD+. Discussion paper (wwwtinyurlcom/nepal-drivers-redd) (accessed April 2016)

82. Wagner A, Yap DLT, Yap HT. 2015. Drivers and consequences of land use patterns in a developing country rural community. Agriculture, Ecosystem and Environment 214:78-85

83. Wasiq M, Ahmad M. 2004. Sustaining forests: A development strategy. The World Bank. Washington DC, USA, 99

84. Weisse M, Peterson R. 2015. How accurate is accurate enough? Examining the GLAD global tree cover change data (Part 1) http://blog.globalforestwatch.org/data/howaccurate-is-accurate-enough-examining-the-glad-global-tree-cover-change-data-part$\underline{1 . h t m l}$ (accessed March 5, 2017) 
85. World Bank. 2016. Migration and Remittances Factbook 2016, 3rd edition. Washington, DC: World Bank. doi:10.1596/978-1-4648-0319-2. 
Table $\mathbf{1}$ (on next page)

Description of the variables used in the model 


\begin{tabular}{|c|c|c|c|}
\hline Variables & Description & Unit & Data source \\
\hline Nefug & $\begin{array}{l}\text { Number of community forestry user groups (CFUGs). CFUG } \\
\text { is a community based local institution that has right to manage } \\
\text { and govern community forests in Nepal's community forestry } \\
\text { program. }\end{array}$ & Number & $\begin{array}{l}\text { Community Forestry National Database } \\
\text { Department of Forest, Government of Nepal } \\
\text { (DoF, 2015) } \\
\text { http://dof.gov.np/image/data/Community\%20 } \\
\text { Forestry/Detail\%20FUG\%20All.pdf }\end{array}$ \\
\hline Refug & $\begin{array}{l}\text { Percentage of major vegetation area (cumulative of trees, } \\
\text { grasslands, shrubs and sparse vegetation areas potential to be } \\
\text { community forests) in the district covered by community } \\
\text { forests. }\end{array}$ & Percentage & $\begin{array}{l}\text { Calculated based on the land cover map and } \\
\text { area of community forest in the district }\end{array}$ \\
\hline Pdensity & $\begin{array}{l}\text { Population density in } 2011 \text { (calculated by dividing population } \\
\text { with the area of a district outside the protected areas) }\end{array}$ & Number/ha & $\begin{array}{l}\text { Central Bureau of Statistics (CBS), } \\
\text { Government of Nepal (CBS, 2012) } \\
\text { http://cbs.gov.np/image/data/Population/Distr } \\
\underline{\text { ict\%20Level\%20Detail\%20Report/Househol }} \\
\text { d_Tables.pdf }\end{array}$ \\
\hline
\end{tabular}


Ppopdensity Density of poor people (calculated by dividing population poor people with the area of a district outside the protected areas)

Rlivest Ratio of total number of livestock with the extent of major vegetation area in a district

Human development index (composite index of life expectancy, education and per capita income)
Number/ha

Calculated here

Number/ha

Calculated here from the data gathered from Promotion and Statistics Division, Ministry of Agricultural Development, Government of Nepal (GoN, 2012a)

http://www.moad.gov.np/en/publication?Publ icationSearch $\% 5$ Bcategory_id $\% 5 \mathrm{D}=13 \& \mathrm{Publ}$ icationSearch $\% 5$ Btitle $\% 5 \mathrm{D}=\&$ PublicationSea $\underline{\operatorname{rch} \% 5 B a d d e d ~ d a t e} \% 5 \mathrm{D}=$

National Planning Commission, Government of Nepal (NPC/UNDP, 2014)

http://www.hdr.undp.org/sites/default/files/ne pal_nhdr_2014-final.pdf 
Fire

Fuelwood Percentage of households using fuelwood for cooking in the district

Total number of fire (pixel) incidence (clipped by the extent of vegetation) from 2001 to 2016 divided by the area of a district outside the protected areas

Migrant Number of migrants from the district gone to overseas for employment (2008-2014)
Rlength Total length of roads

$\mathrm{Km}$

Number

Number/ha

http://modis-

fire.umd.edu/pages/BurnedArea.php?target= GeoTIFF

Department of Foreign Employment, Government of Nepal (GoN, 2014)

https://asiafoundation.org/resources/pdfs/Mig rationReportbyGovernmentofNepal.pdf

Percentage

Calculate here from the data gathered from National Population and Housing Census

(National Report), Central Bureau of Statistics (CBS), Government of Nepal (CBS, 2012)

http://cbs.gov.np/sectoral statistics/populatio $\underline{\text { n/national report }}$ 
Tloss Net change loss in tree cover from 2001-2016

Tgain Net gain in tree cover from 2001-2016

Tchange Net change in tree cover from 2001-2016

Elevation Altitude
Hectare (ha) Global Forest Watch (Hansen et al., 2013)

http://earthenginepartners.appspot.com/scienc e-2013-global-forest/download v1.4.html

Hectare (ha) Global Forest Watch (Hansen et al., 2013)

http://earthenginepartners.appspot.com/scienc e-2013-global-forest/download v1.4.html

Hectare (ha) Calculated here (net gain-net loss)

Meter Shuttle Radar Topographic Mission (SRTM)

Digital Elevation Data (DEMs)

$\underline{\text { https://lta.cr.usgs.gov/SRTM1Arc }}$

Slope

Slope

Calculated from elevation in ArcGIS

1 
Table 2 (on next page)

Coefficients of net change in tree cover 


\begin{tabular}{|c|c|c|c|c|c|}
\hline \multicolumn{2}{|c|}{$\begin{array}{l}\text { Model } 1 \text { Proportion of forest cover } \\
\text { loss }\end{array}$} & \multicolumn{2}{|c|}{$\begin{array}{l}\text { Model } 2 \text { Proportion of forest cover } \\
\text { gain }\end{array}$} & \multicolumn{2}{|c|}{$\begin{array}{l}\text { Model } 3 \text { Proportion of net forest cover } \\
\text { change }\end{array}$} \\
\hline Predictors & Estimate (Std. Error) & Predictors & Estimate (Std. Error) & Predictors & Estimate (Std. Error) \\
\hline (Intercept) & $4.76900(1.21400)^{* * *}$ & (Intercept) & $0.06492(0.16150)$ & (Intercept) & $5.59100(1.2)^{* * *}$ \\
\hline \multirow[t]{2}{*}{ Ncfug } & $-0.00350(0.00090) * * *$ & & & Ncfug & $-0.00390(0.00090)^{* * *}$ \\
\hline & & Rcfug & $0.01273(0.00309)^{* * *}$ & Rcfug & $0.01279(0.00754)$ \\
\hline Rlivest & $-0.00007(0.00004)$ & & & Rlivest & $-0.00005(0.00004)$ \\
\hline Hdi & $-5.75200(2.78700)^{*}$ & & & Hdi & $-8.58600(2.839)^{* *}$ \\
\hline Migrant & $3.37400(1.06000)^{* *}$ & & & Migrant & $2.67700(1.047)^{*}$ \\
\hline \multirow[t]{2}{*}{ Elevation } & $-0.00028(0.00013)^{*}$ & Elevation & $-0.00012(0.00005)$ & Elevation & $-0.00021(0.00013)$ \\
\hline & & Rlength & $0.00008(0.00005)$ & & \\
\hline \multicolumn{2}{|c|}{$\mathrm{R}^{2}=0.4755, \mathrm{p}=0.00002$} & \multicolumn{2}{|c|}{$\mathrm{R}^{2}=0.2842, \mathrm{p}<0.00001$} & \multicolumn{2}{|c|}{$\mathrm{R}^{2}=0.4872, \mathrm{p}<0.00001$} \\
\hline
\end{tabular}


Figure 1

Study area showing the tree cover loss in different districts of Nepal.
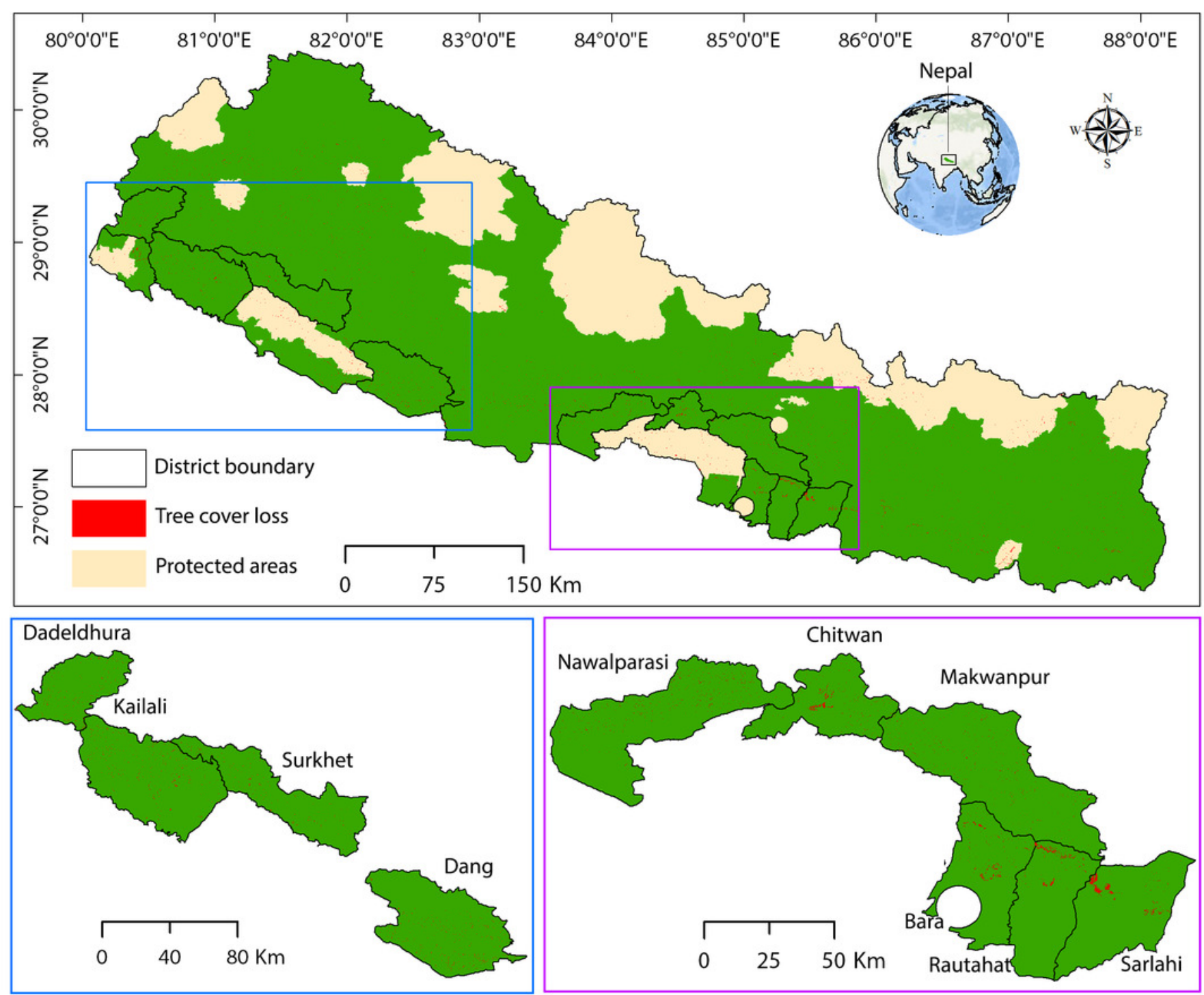
Figure 2

Extent of tree cover change in different districts of Nepal. 


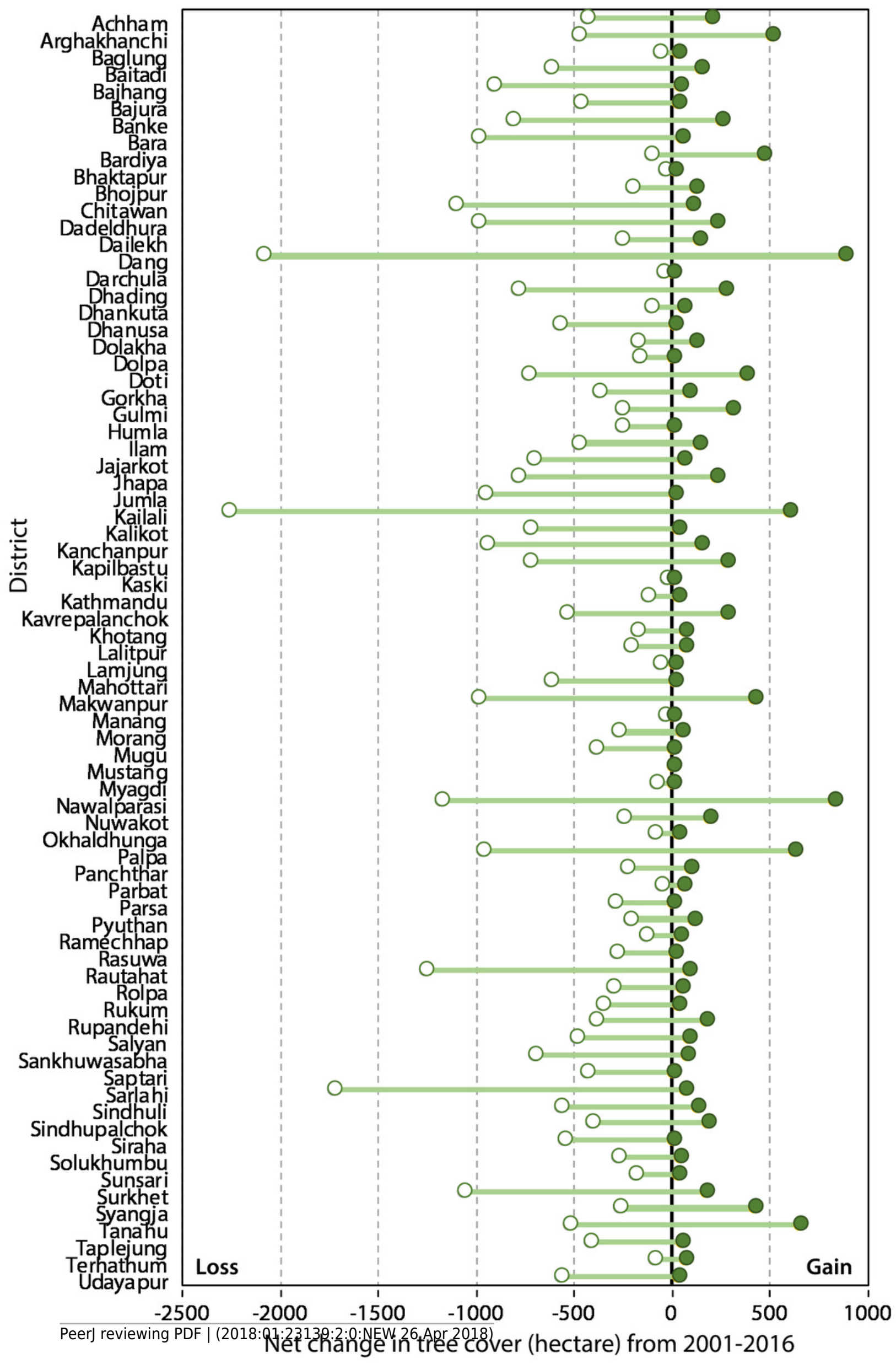


Figure 3

a) Tree cover loss and gain in distance from the road, b) Temporal pattern of tree cover loss in five physiographic regions of Nepal, c) Temporal pattern of tree cover loss with respect to forest fire incidence.
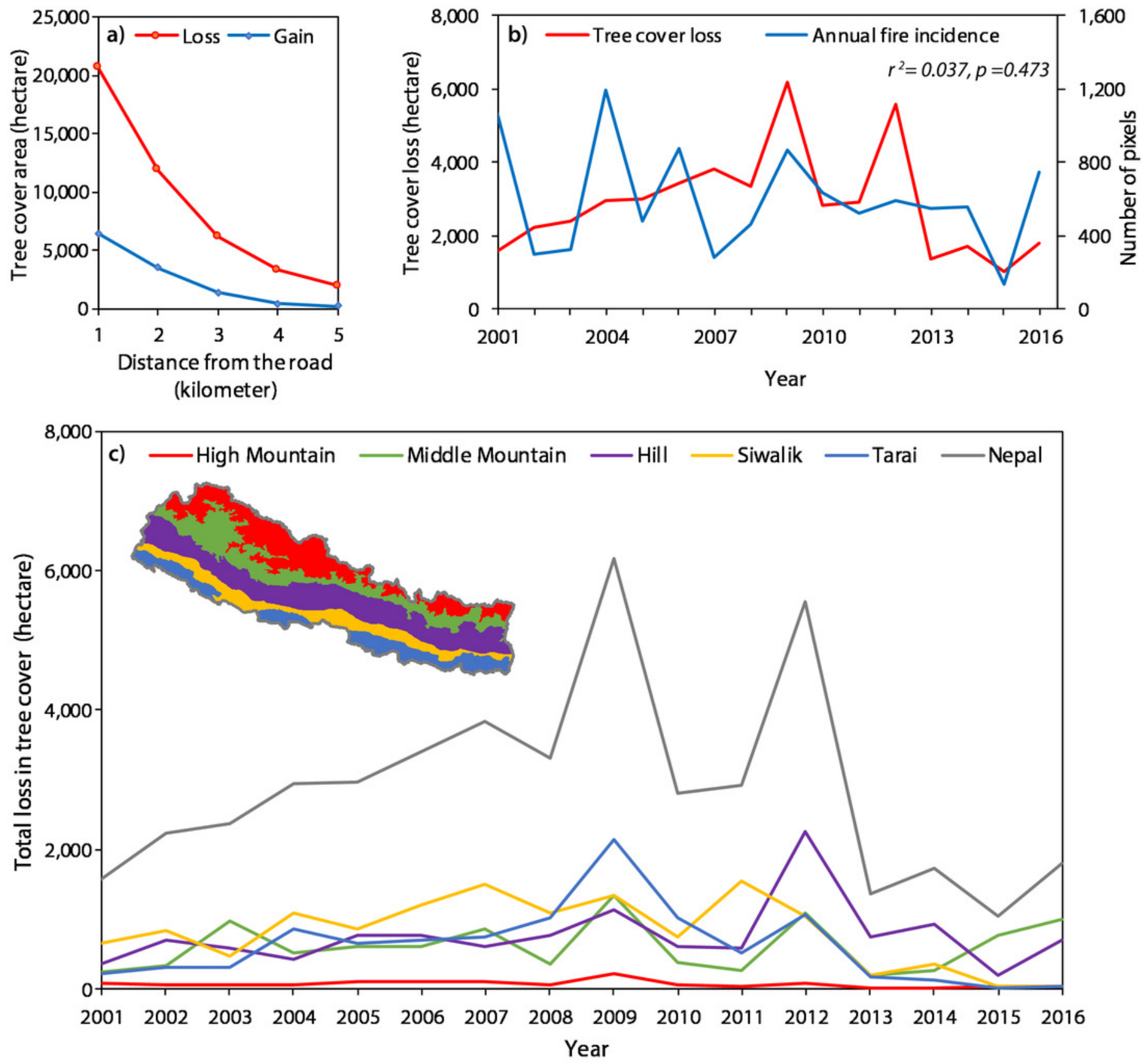